\title{
Modelling for efficient network system design considering physical processes and power consumption
}

\author{
Robertas Alzbutas ${ }^{1,2}$, \\ Tomas Iešmantas ${ }^{1}$, \\ Romualdas Škèma ${ }^{1}$, \\ Tomas Blažauskas² \\ ${ }^{1}$ Lithuanian Energy Institute, \\ Breslaujos Str. 3, \\ LT-44403 Kaunas, Lithuania \\ E-mail:robertas@mail.lei.lt \\ ${ }^{2}$ Kaunas University of Technology, \\ Studentu Str. 50, \\ LT-51368 Kaunas, Lithuania
}

The subject matter of this article is a part of a broader and more complex issue: modelling of physical processes and assessment of various variables, such as power consumption, reliability, etc., for the purpose of designing systems, which involve network nodes affected by physical processes.

The first part of this article is devoted to presentation of the tool called Energy Simulator. This tool is intended for the purpose of modelling of network systems or processes when power consumption is of interest. The Energy Simulator is constructed as a simulation service able to automatically (i. e. without any human action) construct a model from technical specifications and simulate new / innovative network or system designs and estimate energy use for them. Structurally, the Energy Simulator combines the usage of Simple Object Access Protocol together with calculation / simulation environment. This provides with the possibility of scheduling or parallelization of tasks.

For the optimization of existing systems or for designing new ones, consumed energy estimate is a tremendously important part and this new tool could be a handy support for engineers, especially since new governmental laws or directives at the European Union level are being established with strict energy efficiency requirements. The usage of this tool is demonstrated for compressed air systems. We a priori assume that the power consumption in such systems is entirely governed by the thermodynamics of compressed air flow. Implementation of compressed air systems is based on the physical network concept when the system is represented as consisting of functional elements or subsystems that interact with each other by energy flow and variables of physical processes which impact the power consumption.

Key words: power consumption, compressed air systems, network, designing, simulation and modelling

\section{INTRODUCTION}

A system is a group of objects, i. e. elements or subsystems whose interaction serves for a common purpose. Many measures are used to evaluate how closely the design of systems and subsystems meets the desired functionality and constraints. Some of the measures include performance, energy and power consumption, reliability, cost of design and manufacturing.

When designing a system, several choices must be made concerning the type of elements to be used and configuration of their assembly. The choice is driven by the objectives 
with the economic costs, reliability, energy consumption associated to the design implementation, system construction and future operation, etc.

In addition, designing complex engineered artefacts (and collections of them) most likely requires use of simulations coupled with optimization techniques [1]. As complexity increases, ability to employ intuition (even for understanding the computed trade-offs) declines rapidly. Furthermore, person's ability to actually solve these system optimization problems becomes suspect as dimensionality increases.

From all the possible choices of objectives for the system design, our attention was restricted to the analysis of power consumption and the analytical modelling with simulation of physical systems in order to estimate such consumption.

The usual practice when estimating power consumption of a new system is to use, e. g. simplified equations / formulas. [2]. However, such approach could result in heavily pronounced errors if the system is complex because processes, that require the usage of energy-consuming equipment, might be very complicated and related constraints might not be satisfied. The tool that would be able to construct a complex model, simulate it automatically and at the same time could be used by the designer without being exposed to mathematical rigour is of great importance. Such tool would enable the designer to create a new system or process more efficiently and with more adequacy.

In this article the authors present such a tool - Energy Simulator (ES). The general concept is presented where architecture and functionalities are described. Further, ES is demonstrated for the case of a specific compressed air system: from model building of such systems and its numerical implementation to the presentation of how general ES functionalities are used in this specific case.

ES can be further processed in other designing task, for example, optimization in terms of power consumption. One of possible scenarios is to construct a model for the implementation of the existing system and then, according to some strategy, alter configuration of the system and obtain simulation results of this new system. Processing of these results will lead to another alteration of system configuration. Finally, after some number of steps, a new and better system configuration will be found. This new system can then be implemented instead of the old one.

\section{Energy Simulator Tool}

The Energy Simulator is a tool intended for the simulation of network systems or processes, when energy consumption is of interest. ES is constructed as a simulation service able to simulate new / innovative network or system designs and estimate energy use for them. The analytical modelling and simulation are based on "block-based modelling" concept rather than on purely "process-based modelling". It means that the whole physical system or physical process is decomposed into sub-systems or sub-processes represented by independent blocks (one block for one sub-system or sub-process).

- The sub-system is a specific physical equipment (installation) providing process-related output, which depends on process-related boundary conditions and sub-system parameters (block parameters). The sub-system may be expressed using differential equations with specific parameters.

- The sub-process is a process variable (output of block) related to physical behaviour of other variables (inputs of block) with their weighting coefficients (block parameters). The sub-process may be expressed as a process variable or function dependent on other process variables.

The list and relation of blocks together with their parameters give the process configuration, which is the basic information for automatic model generation. The main tasks of ES include the following ES functionalities (for detailed description see the table below):

- Get Configuration;

- Add Blocks;

- Specify Configurations;

- Calculate Energy Use of Process Configuration.

Interaction of ES functionalities and links to other database and user (Energy Analyzer - EA) can be graphically represented as in Fig. 1. A user or Energy Analyzer is meant as other possible software that uses energy consumption estimates as input variables for other type of calculations, e.g. optimization of system configuration.

Two functionalities, namely Specify Connections and Add Blocks, are related to the application of Model Library, which includes predefined models of possible blocks, i. e. all models of sub-systems or sub-processes. This Model Library contains blocks (together with their models), that are specific for the modelling problem at hand.

In accordance with the predefined configuration, initially, the whole system or process is modelled automatically connecting all blocks. This can be visualized by drawing the lines between the related blocks. The connected blocks can be mathematically expressed as the system of differential equations or a single regression function, which relates all process variables. In addition, for the simulation there is a need to perform the evaluation of unknown relations and values, e. g. numerically solve differential equations or evaluate weighting coefficients for process variables.

The output (response variable) of the whole ES system may be any process variable and the energy use, which is calculated depending on the process variables. This is important in case if the user in the specified timescale seeks 
Table 1. Description of ES functionalities

\begin{tabular}{|c|c|}
\hline Functionalities & Description \\
\hline Get Configuration & $\begin{array}{l}\text { Purpose: to get a process configuration and specify the nodes. The user of this functionality is the } \\
\text { internal functionality Add Blocks. } \\
\text { Input: configuration ID. } \\
\text { Output: configuration. } \\
\text { Comment: If database (knowledge repository - KR) is not used and at the initiation time the configura- } \\
\text { tion is accessible in a table form locally, then this functionality is not used. }\end{array}$ \\
\hline Add & $\begin{array}{l}\text { Purpose: to retrieve the characteristics of relevant blocks from the Model Library of the element. The } \\
\text { user of this functionality is the internal functionality Specify Connections. } \\
\text { Input: the blocks listed in the configuration. The Model Library should be accessible for this function- } \\
\text { ality. Each model of blocks shall be represented by mathematical dependencies relating to: } \\
\quad \text { - relevant physical variables; } \\
\text { - energy use and physical variables. } \\
\text { Output: a set of models selected depending on the configuration. } \\
\text { Comment: The configuration contains names of blocks. Their characteristics should be identified and } \\
\text { included into the simulation model. Characteristics are mathematical dependencies of physical vari- } \\
\text { ables or dependencies between energy use and physical variables. }\end{array}$ \\
\hline Specify Connections & $\begin{array}{l}\text { Purpose: to specify the connections between blocks. The user of this functionality is the internal func- } \\
\text { tionality Calculate Energy Use of Process Configuration. } \\
\text { Input: a set of block models. } \\
\text { Output: the model for a specific configuration fully generated for the simulation of the process (sys- } \\
\text { tem) and calculation of energy use. } \\
\text { Comments: Connection might be different in terms of topology (connection points) and character- } \\
\text { istics of connecting branches. The connections should be specified in the configuration. }\end{array}$ \\
\hline $\begin{array}{l}\text { Calculate Energy Use of } \\
\text { Process Configuration }\end{array}$ & $\begin{array}{l}\text { Purpose: to simulate the process (system) and calculate the energy use. } \\
\text { Input: The input is a model for a specific configuration fully generated for the simulation of the pro- } \\
\text { cess (system) and calculation of energy use. } \\
\text { Output: The output may be any simulated physical variable and its time series or / and the energy use, } \\
\text { which may be calculated depending on the physical variables. } \\
\text { Comments: This functionality uses the simulation model generated using other functionalities. }\end{array}$ \\
\hline
\end{tabular}

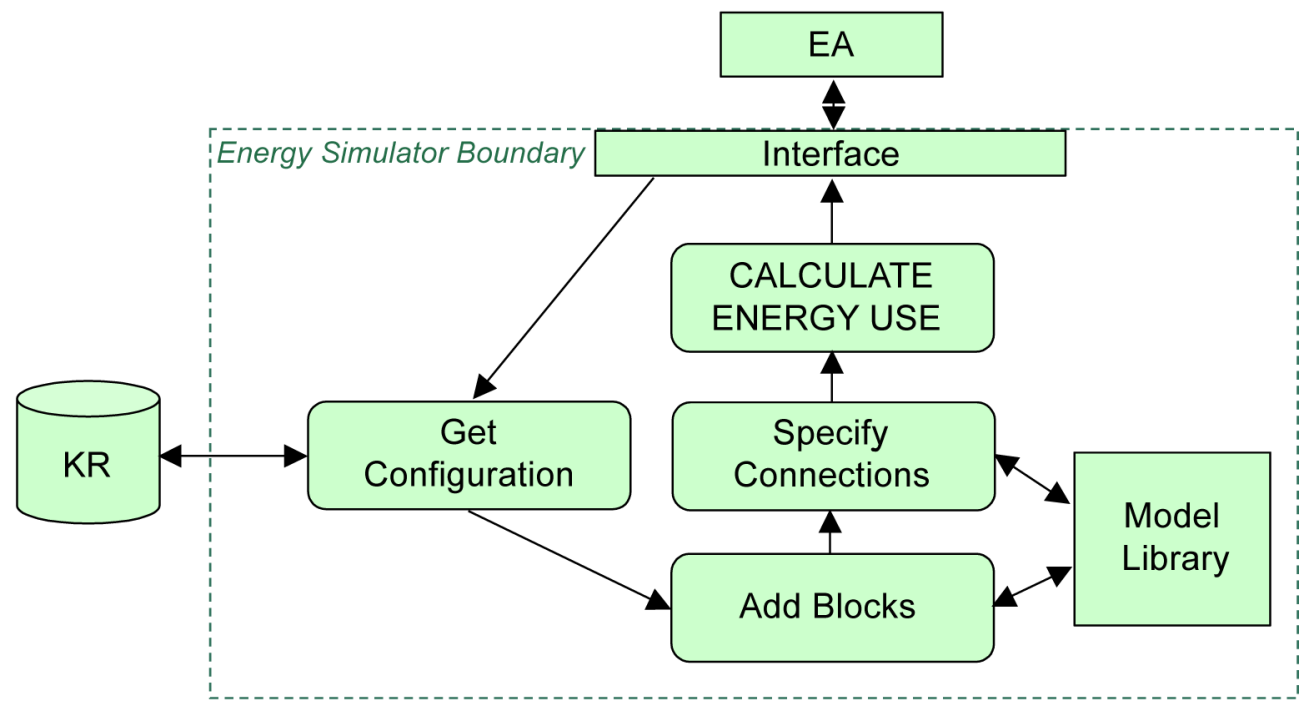

Fig. 1. ES functionalities and links to the database and user

to obtain the time series or single estimates (e. g. average) of energy use and at certain sub-systems or sub-processes to perform verification of critical values (e. g. maximum) of process variables, which in turn should confirm that the process will be operable and compliant with the pre-defined design constraints. The whole flow of data within ES and between outer users can be summarized as in Fig. 2 .
Summarising, the process modelling and energy use simulation include the following phases:

- Configuration-based model generation;

- Simulation of process (system);

- Calculation of energy use.

The last two phases represent the running of the generated model, i. e. simulating the model and performing 


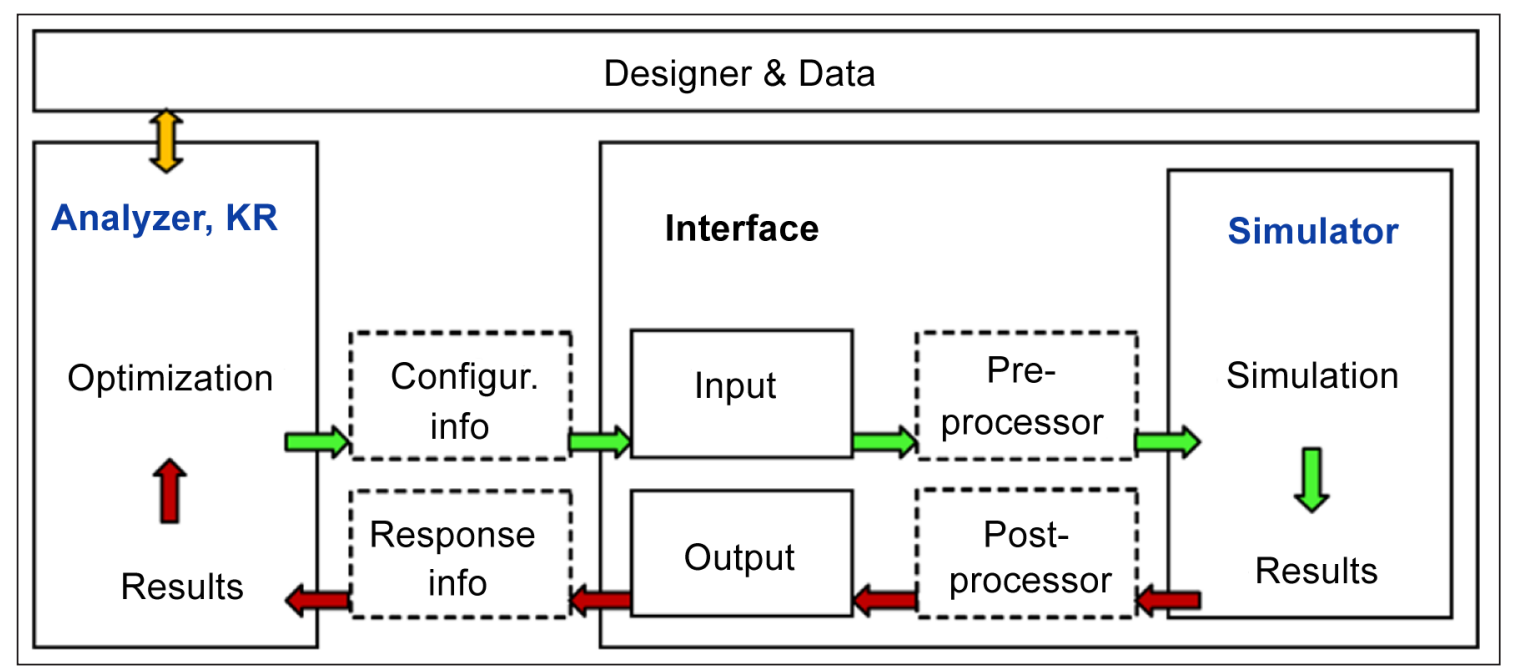

Fig. 2. Interaction between the Analyzer (EA), KR and Simulator (ES)

the calculations, which results are important for Energy Analyzer. All three phases depend on the modelling approach used for a specific system or process. For different cases the configuration, blocks, modelling, simulation and calculation are implemented depending on the used mathematical modelling approach, which itself depends on the considered physical phenomena and available information.

As it was mentioned previously, the calculation of response variables can include the calculation of energy use, which depends on the physical process variables. The process variables may be the same as sub-process variables or may be expressed either as variables of functions or variables of equations, which express the relations (e. g. balance of mass and energy).

In case if energy use is directly calculated on the basis of configuration, which represents the process itself, then values of process variables are not simulated but just expressed as functions or given as time series. Separate blocks as functions or parts of time series may be related to the sub-processes or even some set points, which define these sub-processes. The modelling representing the whole process then automatically connects all sub-processes and is used for the analysis of an innovative design and calculation of energy use.

\section{ES demonstration for compressed air systems}

Compressed air is used widely throughout industry. Almost every industrial plant, from a small machine shop to an immense pulp and article mill, has some type of the compressed air system. In many cases, the compressed air system is so vital that the facility cannot operate without it.

In many industrial facilities, air compressors use more electricity than any other type of equipment. Inefficiencies in compressed air systems can therefore be significant. According to the observations in industry practice, energy saving from system improvements can range from $20 \%$ to $50 \%$ or more of electricity consumption. A properly managed compressed air system can save energy, reduce maintenance, decrease downtime, increase production throughput, and improve product quality. Compressed Air Systems (CAS) consist of a supply side, which includes compressors and air treatment, and a demand side, which includes distribution and storage systems and end-use equipment.

As an important component for power consumption, the notion of pressure drop is applied - a term used to characterize the reduction in air pressure from the compressor discharge to the actual point-of use. Pressure drop occurs as the compressed air travels through the treatment and distribution system. Excessive pressure drop will result in poor system performance and excessive energy consumption. Overall pressure drop together with produced flow rate will make the essential parts in power consumption estimation.

Despite importance of CAS in industrial applications, still not much research has been done about its power consumption or physical process modelling, e. g. Qin and Mckane [3] reported CAS analysis in terms of energy consumption and Kaya et al. [2] quantified energy losses in CAS.

CAS analysis implementation with the ES Tool will be further presented: definition of used blocks, physical modelling, systems topology introduction into configuration, power consumption estimation, application of ES functionalities.

\section{Matlab Simscape environment}

The Energy Simulator concept for compressed air systems was realised under Matlab Simscape ${ }^{\text {twx }}$ computational environment. Simscape software is a set of block libraries and special simulation features for modelling of physical systems in the Simulink ${ }^{\oplus}$ environment. It employs the physical 
network approach, which is particularly suited to simulating systems or processes that consist of real physical elements.

Simscape technology enables to create a network representation of the system under design, based on the physical network approach. According to this approach, each system is represented as consisting of functional elements that interact with each other by variables of physical processes.

These connection ports are bidirectional. They mimic physical connections between elements. User does not have to specify flow directions and information flow when connecting Simscape blocks, just as you do not have to specify this information when you connect real physical elements. The physical network approach automatically resolves all the traditional issues with types of variables, directionality, and so on.

The number of connection ports for each element is determined by the number of energy flows it exchanges with other elements in the system, and depends on the level of the detail. For example, an air compressor in its simplest form can be represented as a two-port element, with energy flow associated with the inlet (suction) and the other with the outlet.

Resulting physical network is described by the so called Differential Algebraic Equations (DAE) of the form [4]:

$$
\left\{\begin{array}{l}
y^{\prime}=f_{1}(t, y, x) \\
0=f_{2}(t, y, x)^{\prime}
\end{array}\right.
$$

where the second equation is algebraic (i. e. free of derivatives), $t$ denotes time, $x$ and $y$ are time-dependent variables. For example:

$$
\left\{\begin{array}{l}
y^{\prime}=t x^{2}+y^{3} \\
x^{2}+y^{2}=1
\end{array}\right.
$$

\section{Main CAS elements}

The main equipment that is used in compressed air systems is as follows:

- Compressors - machines, that are used to increase the pressure of air;
- Air dryers - when air leaves a compressor, it is typically saturated and when it flows through colder parts of a system, water will condensate. This causes detrimental effects, such as corrosion and contamination of pointof-use processes. This problem can be avoided by proper use of dryers and air filters;

- Air filters - depending on the level of air purity required, different levels of filtration and types of filters are used to remove solid particles, lubricants, moisture, etc.;

- Receivers are used to provide compressed air storage capacity for a peak demand and to control system pressure by controlling the rate of pressure change in a system;

- Connectors are used for the purpose to connect several elements in order to represent the distribution of the flow.

These four types of CAS elements are implemented in ES as a Simscape based Model Library of blocks which are used to simulate physical behaviour of the system. We also implemented a block called EndUser. This block denotes the end point of CAS where compressed air is used for various purposes. We also included a block AirSource intended to represent ambient air conditions.

In addition, to be able to measure and monitor various physical characteristics (pressure, air flow rate, etc.) two blocks called FlowSensor and PressureSensor were created.

\section{Mathematical modelling of CAS physics}

As mentioned, Simscape provides environment where real physical systems can be modelled by invoking the physical network notion. One example of CAS represented by the physical network in the Simscape environment using created blocks is in Fig. 3.

Each block model is based on such global assumptions:

- Working fluid is an ideal gas satisfying the ideal gas law.

- Specific heats at constant pressure and constant volume $\left(c_{p}\right.$ and $\left.c_{v}\right)$ are constant.

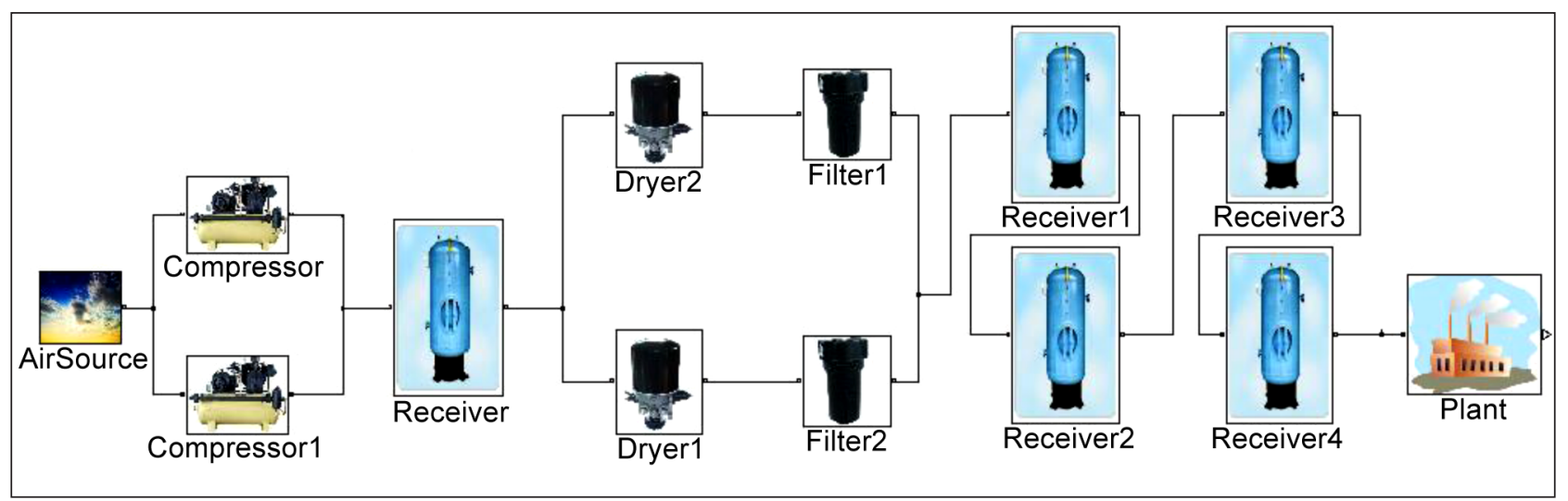

Fig. 3. Example of compressed air system representation by physical network 
- Processes are adiabatic, that is, there is no heat transfer between elements and the environment (except for elements with a separate thermal port).

- Gravitational effects can be neglected, that is, underlying equations contain no head pressures due to gravity. The energy balance for control volume can be expressed as follows [5]:

$$
\begin{aligned}
& \frac{d E_{c v}}{d t}=Q_{c v}-W_{c v}+\sum_{i}\left(m_{i}\left(h_{i}+\frac{1}{2} v_{i}^{2}+g z_{i}\right)\right)+ \\
& +\sum_{o}\left(m_{0}\left(h_{0}+\frac{1}{2} v_{o}^{2}+g z_{o}\right)\right),
\end{aligned}
$$

where $E_{c v}$ is the control volume total energy, $Q_{c v}$ is heat energy per second added to the gas through the boundary, $W_{c v}$ is mechanical work per second performed by the gas, $h_{i}, h_{o}$ are inlet and outlet enthalpies, $v_{i}, v_{o}$ are gas inlet and outlet velocities, $z_{i}, z_{o}$ are elevations at inlet and outlet ports, $m_{i}, m_{0}$ are mass flow rates in and out of the control volume, $g$ is acceleration due to gravity (all units are SI).

The ideal gas law relates pressure $p$, density $\rho$ and temperature $T$ as follows:

$$
p=\rho R T,
$$

where $R$ is a specific gas constant.

Receiver blocks are assembled by inlet, outlet and chamber subblocks. Inlet and outlet are modelled as a constant area pneumatic orifice. Flow rate through the orifice is proportional to the orifice area and the pressure differential across the orifice [6]:

$$
G=C_{d} A p_{i} \sqrt{\frac{2 \gamma}{\gamma-1} \frac{1}{R T_{i}}\left[\left(\frac{p_{o}}{p_{i}}\right)^{\frac{2}{\gamma}}-\left(\frac{p_{o}}{p_{i}}\right)^{\frac{\gamma+1}{\gamma}}\right]},
$$

where $G$ is the mass flow rate, $C_{d}$ is the discharge coefficient to account for effective loss area due to orifice shape, $A$ is the orifice cross-sectional area, $p_{i}, p_{o}$ are absolute pressures at the orifice inlet and outlet, $\gamma$ is the ration of specific heat at constant pressure and constant volume.

The constant volume pneumatic chamber model is based on ideal gas law and a constant specific heat assumption. The continuity equation for the network representation of the constant chamber is as follows [7]:

$$
G=\frac{V}{R T}\left(\frac{d p}{d t}-\frac{p}{T} \frac{d T}{d t}\right)
$$

where $V$ is the chamber volume, $t$ is time.

Filters and dryers are modelled as constructed from inlet, outlet, resistive tube and chamber subblocks. Resistive tube modeless pressure drop due to viscous friction along a short stretch of the pipe with a circular cross section and the chamber represents the volume of the tube. The tube is simulated according to the following equations [6]:

$$
p_{i}-p_{O}=\left\{\begin{array}{l}
\frac{R T_{i}}{p_{i}} \frac{32 \mu L}{A D^{2}} G, \text { laminar flow } \\
f \frac{R T_{i}}{p_{i}} \frac{L}{D} \frac{G^{2}}{2 A^{2}}, \text { turbulent flow }
\end{array},\right.
$$

where $f$ is the friction factor for turbulent flow, $D$ is the tube internal diameter, $L$ is the tube length, $A$ is the cross-sectional area.

Compressors are modelled as perfect flow generators and can be of constant or variable speed and the EndUser (or Plant) is just a sink of infinite volume.

\section{Numerical methods}

In order to obtain a solution for the physical network governed by mathematical laws that were presented in the previous section one needs to employ one of MATLAB differential equation solvers. However, the choice is not a trivial task, due to resulting complexity of the network and the stiffness of the systems of differential algebraic equations. Our search for the most efficient solver resulted in the choice of the trapezoidal rule using a "free" interpolant (in MATLAB software it is denoted by ode23t). Since the physical network gives rise to the previously mentioned DAEs, one needs methods to cope with ordinary differential equations as well as with algebraic equations. Suppose a DAE is like this:

$$
\left\{\begin{array}{l}
u^{\prime}=f_{1}(t, u, v) \\
0=f_{2}(t, u, v)
\end{array} .\right.
$$

Then these equations are to be numerically solved reaching the final time moment $t_{f}$ on the considered time interval $\left[t_{0}, t_{f}\right]$ with the initial condition $u\left(t_{0}\right)=u_{0}$ and the guess value $v_{0}$ for $v\left(t_{0}\right)$ [8]. Assuming that the algebraic equations $0=f_{2}\left(t, u_{0}, v_{0}\right)$ have the solution $V$ near $v_{0}$, the key requirement is that the Jacobian $\partial f_{2} / \partial_{v}$ is non-singular in the region containing $\left(t_{0}, u_{0}, V\right)$. The implicit function theorem [9] implies the existence of the function $R(t, u)$ such that $R\left(t_{0}, u_{0}\right)=V$ and $0=f_{2}(t, u, R(t, u))$. The differential equations are then

$$
u^{\prime}=f_{1}(t, u, R(t, u))=f(t, u)
$$

and the task reduces to solving an initial value problem of an ordinary differential equation. So, each time the integrator needs a value of $f_{1}(t, u, v)$ for the given ones $(t, u)$, the algebraic equations $0=f_{2}(t, u, R(t, u))$ must be first solved for $v$. Then any $n^{\text {th }}$ step with the length $h_{n}$ of the trapezoidal rule is as follows [10]:

$$
u_{n}=u_{n-1}+\frac{1}{2} h_{n}\left[f_{1}\left(t_{n}, u_{n}, v_{n}\right)-f_{1}\left(t_{n-1}, u_{n-1}, v_{n-1}\right)\right] .
$$

This trapezoidal rule is used together with the nonlinear equation solvers step interchangeably. 


\section{Demonstration of ES functionalities}

Although graphical representation of each modelled CAS can be represented as in Fig. 3, it could be emphasised that ES generally operates under virtual Simscape environment, i. e. each CAS that is of interest for the designer and being processed by ES is not represented graphically by default. This rejection of graphical representation is due to the necessity to speed up and automatically simulate different configurations. Handling of configurations could even be carried out by supplying each configuration for different processor node in a multiprocessor machine case.

\section{Get Configuration}

ES due to its architecture is able to function in two ways: when all the information about configurations is stored in the database (possibly in other country, or other geographical location with internet connection) or when no database is present and information is placed in pre-specified ES location. In the first case, when the functionality Get Configuration is initiated by obtaining just configuration ID, ES connects through web interface to the so called Knowledge Repository and collects data associated with ID. In both cases the result is a table (Table 2) representing the network topology of CAS system. In Table 2 NodeName represents the physical and measurement equipment; AltBlockNames denotes the equipment model - different compressor models, filters, etc.; InputNode and InputNodePort represent the way that each block is connected with each other (InputNodePort indicates to which inlet of the component InputNode is being connected).

The obtained configuration includes the physical system topology with links to parameters of blocks and thus it is the input for subsequent functionality Add Blocks.

\section{Add Blocks and Specify Connections}

The functionality Add Blocks is necessary in order to identify and relate each block in configuration to the block in Model Library. During this phase, virtual blocks are col- lected from Model Library and specific parameters are obtained depending on the equipment in the system. For example, compressor model IRN160K2S has the following parameters: MaxFlow $=0.4 \mathrm{~kg} / \mathrm{s}$, MaxPressure $=10$ bars, Power $=160 \mathrm{~kW}$.

Such identification and information collection selecting an appropriate model is done for each block. After each block has assigned parameters, it is placed in a virtual Simscape environment, but does not represent a physical network. The topology of CAS is realised with the functionality Specify Connections. Virtual blocks are connected in accordance with the table, like in Table 2, where InputNode and InputNodePort carry information which and where each block is connected.

\section{Calculate energy use of process configuration}

As already mentioned at the beginning of this section, in each compressed air system pressure drop occurs as air travels through each equipment block. This implies that when one system element is replaced by another with different physical characteristics, then overall pressure drop also will be different.

In addition, if some specific installed CAS is taken under consideration and the designer wants to build a less costly system, then one of criteria is that a new system should be able to satisfy plants air demand equally well as the old system. So, in order to compare different alternatives of the new system, one way to do this is to check that under the same flow demand the resulting pressure drop of new configuration does not lead to inability to supply necessary pressure.

Overall pressure drop together with flow demand is then used to estimate compressor power consumption according to the formula:

$$
P=\frac{\dot{m} \Delta p}{\eta}
$$

where $\dot{m}$ is the volumetric flow rate, $\Delta p$ is the overall pressure drop, $\eta$ is the coefficient of efficiency.

\section{Table 2. The network topology of CAS system}

\begin{tabular}{cccccc}
\hline NodeName & AltBlockNames & InputNode1 & InputNode1 Port & InputNode2 & InputNode2 Port \\
\hline AirSource1 & AirSource & & 0 & 0 \\
\hline Compressor1 & IRN160K2S & AirSource1 & 1 & 0 \\
\hline Compressor2 & IRN160K2S & AirSource1 & 1 & & 0 \\
\hline Receiver1 & Receiver5000 & Compressor1 & 1 & Compressor2 & 1 \\
\hline Dryer1 & D600INA & flowSensor1 & 1 & 0 \\
\hline Filter1 & IRHE1380 & Dryer1 & 1 & 0 \\
\hline Dryer2 & D600INA & flowSensor1 & 1 & Filter2 & 0 \\
\hline Filter2 & IRHE1380 & Dryer2 & 1 & \\
\hline Receiver2 & Receiver750 & Filter1 & 1 & 0 \\
\hline Receiver3 & Receiver750 & Receiver2 & 1 & 0 \\
\hline Receiver4 & Receiver750 & Receiver3 & 1 & & 0 \\
\hline Receiver5 & Receiver750 & Receiver4 & 1 & & 0 \\
\hline EndUser1 & EndUser & Receiver5 & 1 & \\
\hline
\end{tabular}




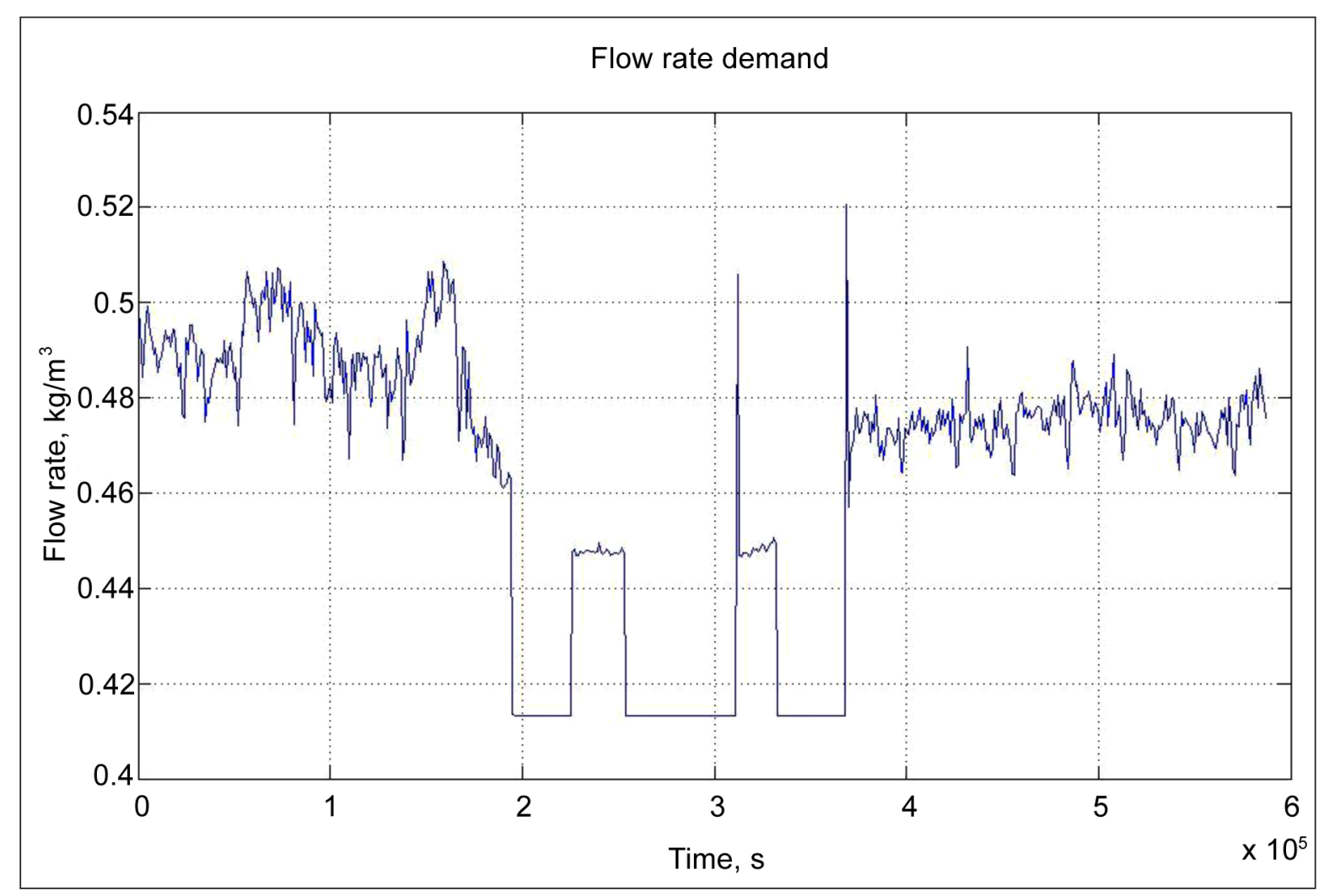

Fig. 4. Flow rate demand of air measure in one week

Suppose that flow rate demand over a week of the plant is like one showed in Fig. 4. This is flow rate-time series that needs to be produced by all compressors. Since the same CAS can have constant and variable speed compressors with different flow capacities, some strategy should be used to control them. In real systems it is usual to have constant speed compressors for the purpose to produce a general level of demand while variable speed compressors are used to catch the top peaks of flow.

The provided flow rate demand was satisfied by the newly designed compressed air system shown above (Fig. 4). Both compressors were identical and of variable speed, but the second one was used very shortly at the largest flow peak. The resulted main characteristics of power consumption are presented in the Table below.

\section{Table 3. Main characteristics of power consumption}

\begin{tabular}{c|c|c}
\hline $\begin{array}{c}\text { Maximum, } \\
\text { kW }\end{array}$ & $\begin{array}{c}\text { Minimum, } \\
\text { kW }\end{array}$ & $\begin{array}{c}\text { Average, } \\
\mathbf{k W}\end{array}$ \\
\hline 202.88 & 1.35 & 58.41 \\
\hline
\end{tabular}

Output of this last functionality can also be measurements like pressure, temperature, and flow rate in some specific system places. Places are of interest for design purposes. These measurements can be further processed by the user or other software dealing with optimization or can just serve as the guidelines for the designer.

\section{CONCLUSIONS}

The presented tool of Energy Simulator proves a valuable framework of modelling for designing of an efficient network system considering physical processes and power consumption. The physical network concept and Simscape environment enabled the representation of real system as a system of differential algebraic equations. In addition, the trapezoidal rule proved to be a way out of the problems caused by stiffness of these equations.

ES functionalities allow this tool to be connected to the external database, in this article called Knowledge Repository. Such connection can be used for obtaining information about a specific system as well as to put results into the database from where it can be processed by another software.

The ES tool is able to provide power consumption as well as pressure and temperature in various places of the virtual model. This flexibility is due to automatic analytical modelling and simulation of physical phenomena. Such measurements in different system locations also enable the designer to make place-specific alterations of system configuration.

In addition, due to Simscape richness of various modelling possibilities and due to flexibility of the ES tool, other network systems as well as processes could be implemented and analyzed in terms of their power consumption. 


\section{ACKNOWLEDGEMENTS}

This research was done under the Project DEMI (Product and Process Design for AmI Supported Energy Efficient Manufacturing Installations) with partial financing from the European Commission under the 7th Framework Programme.

Received 13 March 2013 Accepted 8 May 2013

\section{References}

1. Papalambros P., Michelena N. Trends and challenges in system design optimization. Design. 2002. P. 21542159.

2. Kaya D., Phelan P., Chau Sarac I. Energy conservation in compressed-air systems. International Journal of Energy Research. 2002. Vol. 26. P. 837-849.

3. Qin H. Sh., Mckane A. Improving Energy Efficiency of Compressed Air System Based on System Audit, 2008.

4. Kunkel P., Mehrmann V. Differential-Algebraic Equations - Analysis and Numerical Solution. Zurich, Switzerland: EMS Publishing House, 2006.

5. Moran M., Shapiro H. Fundamentals of Engineering Thermodynamics. Second edition. New York: John Wiley \& Sons, 1992.

6. Beater P. Pneumatic Drives. System Design, Modeling and Control. New York: Springer, 2007.

7. Shapiro $\mathrm{H}$. The Dynamics and Thermodynamics of Compressible Fluid Flow. Vol. 1. New York: John Wiley \& Sons, 1953.

8. Shampine L., Reichelt M., Kierzenka J. Solving Index-1 DAEs in MATLAB and Simulink. SIAM Review. 1999. Vol. 41. P. 538-552.

9. Kudryavtsev D. Implicit function. In: Hazewinkel M. (Ed.). Encyclopedia of Mathematics. Springer, 2001.

10. Ascher U., Petzold L. Computer Methods for Ordinary Differential Equations and Differential Algebraic Equations. Philadelphia, 1998.

Robertas Alzbutas, Tomas Iešmantas, Romualdas Škèma, Tomas Blažauskas

\section{PROJEKTUOJAMŲ ENERGETIŠKAI EFEKTYVIŲ TINKLINIŲ SISTEMŲ MODELIAVIMAS NAGRINĖJANT FIZIKINIUS PROCESUS BEI ENERGIJOS SUVARTOJIMĄ}

\section{Santrauka}

Straipsnio tema yra dalis daug platesnès bei sudètingesnès problemos: fizikinių procesų modeliavimas bei ịvairių parametrų (slègio, patikimumo ir t. t.) vertinimas naujai projektuojamai sistemai, kurios topologija yra tinklinio tipo.

Pirma straipsnio dalis yra skirta naujos priemonès, taip vadinamojo Energijos simuliatoriaus, bei jos pagrindinių funkcijų pristatymui. Tai priemonė, skirta tinklinių sistemų ar procesų modeliavimui, kai reikia žinoti energijos suvartojimą. Energijos simuliatorius sukonstruotas kaip simuliacijų servisas, galintis automatiškai (t. y. be papildomų žmogaus veiksmų) sugeneruoti matematinį modeli pasinaudojant techninemis sistemos / proceso specifikacijomis bei ìvykdyti naujos / inovatyvios sistemos projekto simuliaciją, galiausiai ịvertinant energijos suvartojimą. Energijos simuliatorius sudarytas taikant protokolą SOAP (angl. Simple Object Assess Protocol) ir skaičiavimų / modeliavimo aplinką. Tai suteikia užduočiu vykdymo, tvarkaraščių sudarymo ir jų sugretinimo galimybę.

Jau egzistuojančios ar projektuojamos naujos sistemos optimizavimo procesui ypač svarbus suvartojamos energijos įvertinimas, o Energijos simuliatorius galètų būti kaip pagalbinė priemonè, suteikianti galimybę efektyvesniam optimizavimui vykdyti. Tai taip pat aktualu, kadangi naujuose šalies ịstatymuose, Europos Sąjungos direktyvose yra įtraukiami vis griežtesni energetinio efektyvumo reikalavimai. Naudojama priemonė yra demonstruojama suspausto oro sistemų analizei su prielaida, kad energijos suvartojamas yra lemiamas vien tik suslègto oro srautų termodinamikos. Tokių sistemų imitavimas yra igyvendintas remiantis fizikinio tinklo koncepcija, kai sistema yra apibrèžiama kaip funkcinių elementų ir posistemių (sąveikaujančiu tarpusavy per energijos srautų ir fizikinių kintamųjų procesus, kurie lemia energijos suvartojimą) rinkinys.

Raktažodžiai: energijos vartojimas, suspausto oro sistemos, tinklas, projektavimas, imitavimas ir modeliavimas

Робертас Алзбутас, Томас Иешмантас, Ромуалдас Шкема,

Томас Блажаускас

\section{МОДЕЛИРОВАНИЕ ДЛЯ ЭФФЕКТИВНОГО ПРОЕКТИРОВАНИЯ СЕТЕВОЙ СИСТЕМЫ, УЧИТЫВАЯ ФИЗИЧЕСКИЕ ПРОЦЕССЫ И ПОТРЕБЛЕНИЕ ЭЛЕКТРОЭНЕРГИИ}

Резюме

Предметом настоящей статьи является часть более широкой и сложной проблемы: моделирование физических процессов и оценка различных переменных, таких как энергопотребление, надежность и т. д., с целью разработки систем, которые включают сетевые узлы, находящиеся под влиянием физических процессов.

Первая часть этой статьи посвящена представлению программы (инструмента) под названием Energy Simulator. Этот инструмент предназначен для моделирования сетевых сис- 
тем или процессов и учета потребляемой мощности. Energy Simulator построен как сервис моделирования, который автоматически (т. е. без человеческих действий) может построить модель по определенным техническим характеристикам и моделировать проект новой / инновационной сети или системы и оценить использования энергии для них. Структурно, Energy Simulator сочетает в себе использование протокола SOAP и среды для расчета / моделирования. Это обеспечивает возможность планировать и распределять задачи.

Для оптимизации существующих систем или для разработки новых, оценка потребленной энергии является чрезвычайно важной, и эта новая программа может быть удобной поддержкой для инженеров. Тем более что новые правительственные законы или директивы на уровне Европейского союза создаются со строгими обязательствами учесть эффективность потребления энергии. Использование этого инструмента продемонстрировано на системе сжатого воздуха. Мы априорно считали, что потребление энергии в таких системах полностью обусловлено термодинамикой потока сжатого воздуха. Реализация систем сжатого воздуха основана на физической концепции сети, когда система представлена как состоящая из функциональных элементов или подсистем, которые взаимодействуют друг с другом, учитывая поток энергии и те переменные физических процессов, которые влияют на потребление энергии.

Ключевые слова: потребление электроэнергии, системы сжатого воздуха, сети, проектирование, имитация и моделирование 